\title{
Evaluation and Reselection of Wheat Resistance to Russian Wheat Aphid Biotype 2
}

\author{
Xiangyang Xu,^ Guihua Bai Brett F. Carver, Kehui Zhan, Yinghua Huang, and Dolores Mornhinweg
}

\begin{abstract}
Russian wheat aphid (RWA, Diuraphis noxia, Mordvilko) biotype 2 (RWA2) is virulent to most known RWA resistance genes and severely threatens wheat (Triticum aestivum L.) production in the hard winter wheat area of the U.S. western Great Plains. We determined RWA2 reactions of 386 cultivars from China, 227 advanced breeding lines and recently released cultivars from the United States, 505 landraces from countries where RWA is endemic, and 31 genetic stocks developed in the United States, Australia, Canada, and Russia. The majority of wheat accessions from China and the United States were highly susceptible to RWA2. Only nine landrace accessions produced a homogeneous resistant reaction. In addition, highly resistant plants were identified in 28 heterogeneous landraces. Thus, reselection was conducted to purify some potential resistance sources, and the single-plant progenies of 220 selected plants were evaluated. Homogeneous resistant or highly resistant lines were identified from seven previously heterogeneous landraces. Reselection line PI 626759-20-32 offered a high level of resistance similar to lines carrying $D n 7$, the rye (Secale cereale L.)-derived resistance gene associated with undesirable bread-making quality. PI 626759-20-32 has the potential to supplement or replace $D n 7$ as a new RWA2 resistance source in wheat breeding.
\end{abstract}

X. Xu, Y. Huang, and D. Mornhinweg, Wheat, Peanut and Other Field Crop Research Unit, USDA-ARS, Stillwater, OK 74075; G. Bai, Hard Winter Wheat Genetics Research Unit, USDA-ARS, Manhattan, KS 66506; B.F. Carver, Plant and Soil Science Dep., Oklahoma State Univ., Stillwater, OK 74075; and K. Zhan, Agronomy Dep., Henan Agricultural Univ., 63 Nongye RD, Zhengzou, China, 450002. Received 5 July 2014. *Corresponding author (xiangyang.xu@ars.usda.gov).

Abbreviations: HR, highly resistant; HS, highly susceptible; MR, moderately resistant; MS, moderately susceptible; NSGC, National Small Grains Collection; R, resistant; RWA, Russian wheat aphids; $\mathrm{S}$, susceptible.

$\mathrm{R}$ ussian wheat aphid (RWA, Diuraphis noxia, Mordvilko) is one of the major destructive pests on wheat, having originated from Central Asia and then spreading to East Asia, the Middle East, Africa, North America, South America, and Central Europe (Berzonsky et al., 2003). While feeding on wheat plants, RWA injects a toxin that causes severe damage such as leaf rolling, head trapping, chlorosis, longitudinal streaking, and stunted growth (Berzonsky et al., 2003; Smith et al., 1992). In the United States, RWA was first detected in 1986 and, as a result, losses exceeding $\$ 1$ billion were reported for small grain production in the western United States from 1986 to 1997 (Porter et al., 1998).

Host-plant resistance has played an important role in the management of RWA. To date, a total of 14 named RWA resistance genes have been identified and designated as Dn1 to Dn9 plus Dnx, Dny, Dn2401, Dn626580, and Dn1881. Genes confirmed present in wheat germplasm were Dn1 in PI 137739 (Liu et al., 2001), Dn2 in PI 262660 (Liu et al., 2001; Ma et al., 1998), Dn4 in PI 372129 (Lapitan et al., 2007; Ma et al., 1998),

Published in Crop Sci. 55:1-7 (2015).

doi: 10.2135/cropsci2014.07.0473

(C) Crop Science Society of America | 5585 Guilford Rd., Madison, WI 53711 USA

All rights reserved. No part of this periodical may be reproduced or transmitted in any form or by any means, electronic or mechanical, including photocopying, recording, or any information storage and retrieval system, without permission in writing from the publisher. Permission for printing and for reprinting the material contained herein has been obtained by the publisher. 
Dn6 in PI 243781 (Marais et al., 1994), Dn626580 in PI 626580 (Valdez et al., 2012), Dnx in PI 220127 (Liu et al., 2001), and Dny in Stanton (Smith et al., 2004). Dn5, Dn8, and Dn9 were found in PI 294994 (Liu et al., 2001). The germplasm CI 2401 carries two resistance genes: one allelic to Dn4 on the long arm of chromosome 1D, and another, Dn2401, on chromosome 7D (Dong et al., 1997). Of these, PI 137739, PI 243781, and PI 626580 are Iranian landraces, and CI 2401 is a Tajikistani landrace. The RWA resistance gene in Stanton, a U.S. cultivar developed in Kansas, originated from PI 220350 (Martin et al., 2001). Both PI 220350 and PI 220127 are landraces collected from Afghanistan. PI 262660 and PI 372129 are cultivars developed in Azerbaijan and Turkmenistan, respectively, and PI 294994 was collected from Bulgaria.

Dn3, Dn7, and Dn1881 are three known RWA resistance genes that originated in wheat relatives. $D n 7$ originated in the rye cultivar Turkey 77 and was transferred to wheat cultivar Gamtoos. The resulting line, 93M370, is highly resistant to RWA2 (Marais et al., 1994). Gamtoos carries a $1 \mathrm{RS} / 1 \mathrm{BL}$ chromosome translocation that facilitated a recombination with the 1RS chromosome arm of Turkey 77. Dn3 and Dn1881 were identified in T. tauschii accession SQ24 (Nkongolo et al., 1991) and T. turgidum line 1881 (Navabi et al., 2004), respectively.

Although some resistance genes, such as Dn4 and Dny, have been deployed in some commercial cultivars (Haley et al., 2004b; Quick et al., 1996; Quick et al., 2001a; Quick et al., 2001b; Quick et al., 2001c; Quick et al., 2001d), the adaptive ability of RWA to overcome plant resistance via biotypic differentiation has prompted efforts to diversify RWA resistance genes in wheat breeding programs. In 2003, RWA2 was virulent to almost all resistance genes available except $D n 7$ when it was first detected in southeastern Colorado (Haley et al., 2004a). However, the rye-derived Dn7 associates with undesirable bread-making quality because the 1RS chromosome arm of 93M370 also harbors Sec1 that codes for monomeric secalins (Graybosch et al., 1990). Secalins cause sticky dough and reduce dough strength (Martin and Stewart 1990; Graybosch et al., 1993), and the replacement of the wheat $1 \mathrm{BS}$ arm with 1RS results in the loss of wheat storage protein genes such as Tri-B1, Glu-B3, and Gli-B1 on the 1BS wheat chromosome (Dhaliwal and MacRitchie 1990; Mago et al., 2002; Singh and Shepherd 1988). Therefore, minimizing the size of the translocated segment from $1 \mathrm{RS}$ is crucial for the successful use of the $D n 7$ gene.

More recently, six novel RWA biotypes named RWA3 to RWA8 were identified in the United States (Burd et al., 2006; Weiland et al., 2008). The emergence of these new biotypes highlights the urgency of identifying novel resistance genes to withstand these new biotypes.

The objectives of this study were to more broadly ascertain novel sources of RWA2 resistance in several pivotal international wheat collections with preference given
Table 1. Reselection of wheat resistance to RWA2 from 15 Iranian landraces. For heterogeneous lines, the percentage of each reaction type was given in the following brackets.

\begin{tabular}{|c|c|c|}
\hline Landraces & Selected lines & Reaction types $^{\dagger}$ \\
\hline PI 626759 & PI 626759-20-32 & $\mathrm{HR}$ \\
\hline PI 627843 & PI 627843-18-6 & $\mathrm{R}$ \\
\hline PI 626612 & PI 626612-3-6 & $\mathrm{R}$ \\
\hline PI 626926 & PI 626926-1-1 & $\mathrm{R}$ \\
\hline PI 627625 & PI 627625-1-7 & $\mathrm{R}$ \\
\hline PI 627628 & PI 627628-1-1-17 & $\mathrm{R}$ \\
\hline PI 624151 & PI 624151-1-2 & $\mathrm{R}$ \\
\hline \multirow[t]{2}{*}{ PI 627410} & PI 627410-15-5 & HR (40\%), R (60\%) \\
\hline & PI 627410-23-1 & HR (14\%), R (64\%), HS (22\%) \\
\hline PI 625893 & PI 625893-1-10-19 & R (40\%), HS (60\%) \\
\hline PI 627583 & PI 627583-3-2 & R (50\%), S (50\%) \\
\hline PI 628178 & PI 628178-20-4 & MR \\
\hline PI 627681 & PI 627681-23-16 & MR \\
\hline PI 627727 & PI 627727-385-5-15 & MR \\
\hline PI 627687 & PI 627687-6-1 & MR \\
\hline PI 628178 & PI 628178-20-5 & MR \\
\hline
\end{tabular}

${ }^{\dagger} \mathrm{HR}$, highly resistant; R, resistant; MR, moderate resistance.

to germplasm void of rye chromosome fragments associated with undesired quality traits.

\section{MATERIALS AND METHODS}

Plant materials used in this study included the following: (i) 386 cultivars that are currently planted in the Huang-Huai Facultative Winter Wheat Zone or Middle and Lower Yangtze Valley Autumn-sown Spring Wheat Zone of China; (ii) 227 recently tested advanced breeding lines and cultivars from the United States, 205 of which were previously described (Zhang et al., 2010), and another 22 elite cultivars are parental lines used for genetic studies at USDA-ARS, Manhattan, KS; (iii) 505 landraces collected from countries where RWA is endemic including 464 from Iran, 30 from Afghanistan, two from Kazakhstan, two from the United States, and one each from Azerbaijan, Bulgaria, Egypt, Kyrgyzstan, Serbia, Sweden, and Tajikistan; (iv) 31 genetic stocks, mainly wheat-alien addition lines and translocation lines provided by the USDA-ARS National Small Grains Collection (NSGC) and collected from the United States (21 accessions), Australia (6), Canada (3), and Russian Federation (1); and (v) 220 reselection lines from 15 Iranian landraces. The 505 landraces were selected based on preliminary results of screening 761 germplasm lines from the USDA-ARS NSGC.

In our preliminary studies, the 15 Iranian landraces in group (v) (Table 1) showed a heterogeneous reaction to RWA2. We rescued resistant plants on completion of the RWA assays, vernalized them at $4^{\circ} \mathrm{C}$ for $6 \mathrm{wk}$, and grew them in a greenhouse at the Wheat, Peanut, and Other Field Crop Research Unit of USDAARS to produce seeds. In the subsequent seasons, progenies of these resistant plants were further tested and selected for one or two additional assays, and all resulting lines (reselections hereafter) were evaluated for RWA2 resistance in this study.

For the RWA assays, four seeds per entry were planted in each cell of a 73-cell growing tray (Growing Systems, Inc.) containing Sunshine Redi-earth growing mix (SubGro Horticulture Cabada Ltd.) using a randomized complete block design with 
two replicates. Each entry of plant materials described above in group (i), (ii), and (v) were planted in five cells (20 seeds) as a replicate. A total of 73 cells were planted in each flat, including 70 cells for the test entries, two for the susceptible check ('Yuma') and one for the resistant check ('Yumar', a near isogenic line of 'Yuma' with gene Dn7). Each entry of those in groups (iii) and (iv) was planted in three cells (12 seeds) as one replicate because of the limited amount of seeds provided by NSGC.

RWA2 were cultured on a susceptible barley (Hordeum vulgare L.) in a USDA greenhouse at Stillwater, OK. About 40 seeds were planted into a $15-\mathrm{cm}$ pot of fritted clay, and culture plants were enclosed with a cylindrical plastic cage $(30 \mathrm{~cm}$ tall $)$ vented on the side and top. Culture plants were infested with about 60 aphids per pot at $4 \mathrm{~d}$ after emergence. After 4 wk of aphid population development, typically, there were over 100 aphids on each leave, and these leaves were used to infest test plants.

Test seedlings were infested with RWA 2 at $2 \mathrm{~d}$ post emergence (7 $\mathrm{d}$ after planting) by placing heavily infested leaves close to each row of test plants. Each plantlet was infested with an initial density of about 30 aphids per plant. The RWA assay was conducted in a greenhouse with supplemental daylight of $16 \mathrm{~h}$ at $22 \pm 0.5^{\circ} \mathrm{C}$.

Three weeks after infestation, leaf damage was scored using a 1 to 6 scale as follows: 1, healthy looking plants or small isolated chlorotic spots accounting for up to $5 \%$ of the leaf area; 2 , larger chlorotic spots on up to $20 \%$ of the total leaf area; 3 , chlorotic spots on up to $40 \%$ of the total leaf area, with a tendency of the chlorosis to appear streaky; 4, chlorotic spots accounting for 40 to $60 \%$ of the total leaf area (chlorotic streaks were visible or leaves tended to roll lengthwise); 5, 60 to $80 \%$ of leaf area was chlorotic or leaves rolled tightly; and 6, more than $80 \%$ of leaf area was chlorotic, and plants were wilting or dead. Based on this scale, we interpreted the 1 to 6 damage score to indicate highly resistant $(1=\mathrm{HR})$, resistant $(2=\mathrm{R})$, moderately resistant $(3=\mathrm{MR})$, moderately susceptible (4 = MS), susceptible $(5=\mathrm{S})$, and highly susceptible $(6=\mathrm{HS})$.

Based on initial results, a subset of the germplasm was chosen for validation testing based on two criteria: (i) accessions showed homogeneous resistance or moderate resistance, and (ii) accessions contained highly resistant plants. The validation experiment used a randomized complete block design with three replicates, and a total of 20 plants per entry were tested in each replicate. Experimental conditions and evaluation criteria were the same as those used in the initial assay.

\section{RESULTS AND DISCUSSION Chinese Cultivars are Highly Susceptible to RWA2}

Among the 358 Chinese cultivars evaluated, most were highly susceptible $(76.3 \%)$, susceptible $(21.0 \%)$, or moderately susceptible $(2.5 \%)$ to RWA2, and only cultivar Huangming 116 showed moderate resistance. Resistant and highly resistant cultivars were not identified. These susceptible cultivars showed clear symptoms within $1 \mathrm{wk}$ after infestation, and most of them started wilting or dying within $10 \mathrm{~d}$ of infestation. In this experiment, Yuma, the susceptible check without any known resistance gene, started wilting or dying about $18 \mathrm{~d}$ after infestation. Thus, most of the Chinese cultivars sampled in this study are even more susceptible than the susceptible check Yuma. RWA2 resistance may be extremely limited within the elite wheat gene pool of China.

This lack of resistance may be expected given that RWA pressure has been generally low within the major wheat-growing regions of China from where these cultivars were collected. In China, RWA was first reported in the Xinjiang Uyghur Autonomous Region in 1975, and its origin is still under debate, although most Chinese entomologists consider it an invasive pest there (Zhang et al., 1999a, 1999b; Zhang et al., 2012). The annual wheatgrowing area of Xinjiang Uyghur Autonomous Region is about 1 million ha, accounting for $3.3 \%$ of the total wheat area in China (He et al., 2001), but none of the cultivars examined in this study was collected there. The dry climate in Xinjiang Uyghur Autonomous Region is conducive to the survival of RWA, which is adapted to the arid climates. A recent study revealed that RWA populations are highly diverse with widespread sexual reproduction in that region, and aphid populations may expand into new areas via natural pathways such as wind currents and flight (Zhang et al., 2012). The paucity of RWA 2 resistance found in this study may call for preventative breeding measures to introgress RWA resistance in the event an RWA endemic may occur, even though the RWA has not been reported there yet.

\section{Russian Wheat Aphids Biotype 2 Resistant Lines are Still Rare in the United States}

With the occurrence of RWA2, U.S. wheat breeders have focused on identification and introgression of novel sources of resistance (Collins et al., 2005; Valdez et al., 2012). In this study, we tested a total of 227 advanced breeding lines and cultivars recently released in the United States, and 99\% were rated as susceptible reaction types (HS, S, and MS) with 59\% as HS, indicating that the majority of elite wheat breeding lines and cultivars from the major winterwheat growing areas remain susceptible to RWA2.

In this collection, only one line, STARS 0601W (OK03825), is highly resistant and carries the Dn7 gene (Porter et al., 2007). STARS 0601W, together with 241411 , are currently being used as sources of resistance in the Oklahoma wheat-breeding program. The RWA resistance gene in 2414-11 was mapped on a 1BL.1RS wheat-rye translocation chromosome fragment (Peng et al., 2007) and also determined to be $D n 7$ (http://wheatpedigree.net/ sort/show/833). Some advanced breeding lines with $D n 7$ gene are currently being tested at Oklahoma State University (B.F. Carver, personal communication, 2014). Another line, TX04A001246, derived from a cross "TX95V4339/ TX94VT938-6," showed moderate resistance. However, the resistance gene in TX04A001246 may also be from rye because TX94VT938-6 is a triticale ( $\times$ Triticosecal spp.) line. This needs further research to confirm. 
Table 2. Wheat accessions producing a homogeneous reaction for high resistance $(\mathrm{HR})$, resistance $(\mathrm{R})$, and moderate resistance (MR) to RWA2.

\begin{tabular}{|c|c|c|c|}
\hline Accession & Origin & Score $^{\dagger}$ & $\begin{array}{l}\text { Reaction } \\
\text { type }\end{array}$ \\
\hline PI 386148 & Russian Federation & 1 & $\mathrm{HR}$ \\
\hline Cltr 2401 (PI 9781) & Khujand, Tajikistan & 2 & $\mathrm{R}$ \\
\hline PI 625134 & Markazi, Iran & 2 & $\mathrm{R}$ \\
\hline PI 626115 & Kerman, Iran & 2 & $\mathrm{R}$ \\
\hline PI 626588 & Yazd, Iran & 2 & $\mathrm{R}$ \\
\hline PI 623825 & West Azerbaijan, Iran & 2 & $\mathrm{R}$ \\
\hline PI 624609 & Hamadan, Iran & 2 & $\mathrm{R}$ \\
\hline PI 626404 & Esfahan, Iran & 2 & $\mathrm{R}$ \\
\hline PI 626575 & Esfahan, Iran & 2 & $\mathrm{R}$ \\
\hline PI 626643 & Yazd, Iran & 2 & $\mathrm{R}$ \\
\hline PI 245405 & Afghanistan & 3 & MR \\
\hline Pl 48650 & Iran & 3 & MR \\
\hline PI 621048 & West Azerbaijan, Iran & 3 & MR \\
\hline PI 625524 & Khorasan, Iran & 3 & MR \\
\hline PI 626054 & Kerman, Iran & 3 & MR \\
\hline PI 626080 & Kerman, Iran & 3 & MR \\
\hline PI 626091 & Kerman, Iran & 3 & MR \\
\hline PI 626122 & Kerman, Iran & 3 & MR \\
\hline PI 626208 & Kerman, Iran & 3 & MR \\
\hline PI 626410 & Esfahan, Iran & 3 & MR \\
\hline PI 626423 & Esfahan, Iran & 3 & MR \\
\hline PI 626582 & Yazd, Iran & 3 & MR \\
\hline PI 627399 & Gilan, Iran & 3 & MR \\
\hline PI 627554 & West Azerbaijan, Iran & 3 & MR \\
\hline PI 627569 & Semnan, Iran & 3 & MR \\
\hline PI 627603 & Zanjan, Iran & 3 & MR \\
\hline
\end{tabular}

† The leaf damage was scored using a 1-to- 6 scale. A damage score of 1 to 6 represents highly resistant $(H R)$, resistant $(R)$, moderately resistant $(M R)$, moderately susceptible (MS), susceptible (S), and highly susceptible (HS), respectively.

\section{Novel Resistant Germplasm}

Among 505 landraces and 31 genetic stocks evaluated, 26 accessions (including 25 landraces and one genetic stock) were found to be homogeneously resistant. Of them, PI 386148, a triticale line developed in Russia, was highly resistant. Nine accessions, including CItr 2401, PI 625134, PI 626115, PI 626588, PI 623825, PI 624609, PI 626404, PI 626575, and PI 626643, were rated as R, and 16 accessions were MR (Table 2). Repeated tests confirmed these results and suggested that these accessions can be directly used in wheat breeding to enhance RWA resistance. Among these homogeneously resistant accessions, CItr 2401 was the only one that was previously characterized using molecular markers, of which Dn4 and Dn2401 were reported to confer resistance to RWA1 (Dong et al., 1997). However, Dn4 is ineffective against RWA2, so the genes that confer RWA2 resistance in this accession remains to be investigated.

Among the landraces screened, 28 Iranian wheat landraces showed heterogeneous reactions to RWA2 infestation with varying frequencies of HR plants (Table 3). Among them, 11 accessions contained the most HR plants (frequencies of 50-88\%), including PI 624656, PI
Table 3. Wheat accessions producing a heterogeneous reaction to RWA2 but with some highly resistant (HR) plants, their origins, observed reaction types, dominant reaction types $(\geq 50 \%)$, and percentages of HR plants.

\begin{tabular}{|c|c|c|c|c|}
\hline $\begin{array}{l}\text { Germ- } \\
\text { plasm }\end{array}$ & Origin & $\begin{array}{l}\text { Observed reac- } \\
\text { tion types }\end{array}$ & $\begin{array}{c}\text { Dominant } \\
\text { reaction } \\
\text { type }^{\dagger}\end{array}$ & $\begin{array}{l}\% \text { of } \\
\text { HR } \\
\text { plants }\end{array}$ \\
\hline PI 624656 & Kordestan, Iran & $\mathrm{HR}, \mathrm{R}, \mathrm{MS}$ & $\mathrm{HR}$ & 70.0 \\
\hline PI 625154 & Markazi, Iran & $\mathrm{HR}, \mathrm{MR}$ & $\mathrm{HR}$ & 81.8 \\
\hline PI 625158 & Markazi, Iran & $\mathrm{HR}, \mathrm{R}, \mathrm{MR}$ & $\mathrm{HR}$ & 66.7 \\
\hline PI 626635 & Yazd, Iran & $\mathrm{HR}, \mathrm{R}, \mathrm{MR}$ & $\mathrm{HR}$ & 75.0 \\
\hline PI 626639 & Yazd, Iran & $\mathrm{HR}, \mathrm{R}$ & $\mathrm{HR}$ & 88.0 \\
\hline PI 627410 & East Azerbaijan, Iran & $\mathrm{HR}, \mathrm{R}, \mathrm{S}$ & $\mathrm{HR}$ & 58.3 \\
\hline PI 626151 & Kerman, Iran & $\mathrm{HR}, \mathrm{S}$ & $\mathrm{HR}$ & 84.2 \\
\hline PI 626164 & Kerman, Iran & $\mathrm{HR}, \mathrm{R}, \mathrm{MR}, \mathrm{MS}$ & $\mathrm{HR}$ & 60.0 \\
\hline PI 628151 & East Azerbaijan, Iran & $\mathrm{HR}, \mathrm{R}, \mathrm{MR}$ & $\mathrm{HR}$ & 50.0 \\
\hline PI 627970 & Hamadan, Iran & $\mathrm{HR}, \mathrm{R}, \mathrm{MS}$ & $\mathrm{HR}$ & 81.8 \\
\hline PI 626759 & Yazd, Iran & $\mathrm{HR}, \mathrm{R}$ & $\mathrm{HR}$ & 60.0 \\
\hline PI 626584 & Yazd, Iran & $\mathrm{HR}, \mathrm{R}, \mathrm{MR}$ & $\mathrm{R}$ & 15.4 \\
\hline PI 626636 & Yazd, Iran & $\mathrm{HR}, \mathrm{R}, \mathrm{MR}$ & $\mathrm{R}$ & 9.1 \\
\hline PI 626638 & Yazd, Iran & $\mathrm{HR}, \mathrm{R}, \mathrm{MR}, \mathrm{MS}, \mathrm{HS}$ & $\mathrm{R}$ & 11.1 \\
\hline PI 628043 & Yazd, Iran & $\mathrm{HR}, \mathrm{R}, \mathrm{MR}$ & $\mathrm{R}$ & 21.4 \\
\hline PI 627976 & Hamadan, Iran & $\mathrm{HR}, \mathrm{R}, \mathrm{MR}$ & $\mathrm{R}$ & 21.4 \\
\hline PI 627977 & Hamadan, Iran & $\mathrm{HR}, \mathrm{R}, \mathrm{MR}$ & $\mathrm{R}$ & 13.3 \\
\hline PI 626021 & Khorasan, Iran & $\mathrm{HR}, \mathrm{R}, \mathrm{MR}, \mathrm{HS}$ & MR & 6.3 \\
\hline PI 627391 & Bakhtaran, Iran & $\mathrm{HR}, \mathrm{R}, \mathrm{MR}, \mathrm{MS}$ & MR & 8.3 \\
\hline PI 627967 & Hamadan, Iran & $\mathrm{HR}, \mathrm{R}, \mathrm{MS}, \mathrm{S}$, & $S$ & 5.6 \\
\hline PI 627628 & Khorasan, Iran & $\mathrm{HR}, \mathrm{R}, \mathrm{MS}$ & MS & 6.7 \\
\hline PI 627968 & Hamadan, Iran & $\mathrm{HR}, \mathrm{MS}, \mathrm{HS}$ & & 2.0 \\
\hline PI 627969 & Bakhtaran, Iran & $\mathrm{HR}, \mathrm{R}, \mathrm{MR}, \mathrm{MS}, \mathrm{S}$ & & 7.7 \\
\hline PI 627971 & Hamadan, Iran & $\mathrm{HR}, \mathrm{R}, \mathrm{MR}, \mathrm{MS}$ & & 4.5 \\
\hline PI 627972 & Markazi, Iran & $\mathrm{HR}, \mathrm{R}, \mathrm{MR}, \mathrm{MS}, \mathrm{S}$ & & 5.9 \\
\hline PI 627973 & Markazi, Iran & $\mathrm{HR}, \mathrm{R}, \mathrm{MR}, \mathrm{MS}$ & & 11.1 \\
\hline PI 627974 & Markazi, Iran & $\mathrm{HR}, \mathrm{R}, \mathrm{MR}, \mathrm{MS}, \mathrm{S}$ & & 6.3 \\
\hline PI 627975 & Hamadan, Iran & $\mathrm{HR}, \mathrm{R}, \mathrm{MR}, \mathrm{MS}$ & & 16.7 \\
\hline
\end{tabular}

${ }^{\dagger} \mathrm{HR}$, highly resistant; R, resistant; MR, moderately resistant; MS, moderately susceptible; S, susceptible; HS, highly susceptible.

625154, PI 625158, PI 626635, PI 626639, PI 627410, PI 626151, PI 626164, PI 628151, PI 627970, and PI 626759. Another six accessions, including PI 626584, PI 626636, PI 626638, PI 628043, PI 627976, and PI 627977, contained mostly R plants (>50\%) but some HR plants (9.121.4\%). The remaining 11 accessions contained only a few HR plants (2.0-16.7\%) with the majority of plants rated as other reaction types. Given that all 28 accessions are landraces, it is unlikely that the RWA resistance genes present in these accessions would be Dn 7 originating from rye. Thus, purification of HR genotypes from these accessions should allow us to produce lines with novel genes offering a high level of resistance to RWA2.

In addition, $\mathrm{R}$ plants were also identified in another 122 landraces showing differential reactions to RWA2 infestation. Resistant plants were predominant (50-91\%) in 31 of them (Table 4). Purification, characterization, and utilization of these $\mathrm{R}$ plants in wheat breeding will greatly diversify 
Table 4. Wheat germplasm showing a heterogeneous reaction to RWA2 but with a majority $(\geq 50 \%)$ of plants rated as resistant $(\mathrm{R})$, their origins, observed reaction types to RWA2, and percentages of $R$ plants.

\begin{tabular}{|c|c|c|c|c|}
\hline $\begin{array}{l}\text { Germ- } \\
\text { plasm }\end{array}$ & Origin & $\begin{array}{c}\text { Observed } \\
\text { reaction } \\
\text { types }^{\dagger}\end{array}$ & $\begin{array}{c}\text { Dominant } \\
\text { reaction } \\
\text { type }^{\dagger}\end{array}$ & $\begin{array}{l}\% \text { of } R \\
\text { plants }\end{array}$ \\
\hline PI 625142 & Markazi, Iran & R, MS, HS & $\mathrm{R}$ & 60.0 \\
\hline PI 625145 & Markazi, Iran & $\mathrm{R}, \mathrm{MS}, \mathrm{HS}$ & $\mathrm{R}$ & 75.0 \\
\hline PI 626643 & Yazd, Iran & $\mathrm{R}, \mathrm{MR}$ & $\mathrm{R}$ & 90.9 \\
\hline PI 626107 & Kerman, Iran & $\mathrm{R}, \mathrm{MR}$ & $\mathrm{R}$ & 90.9 \\
\hline PI 626110 & Kerman, Iran & $\mathrm{R}, \mathrm{MR}$ & $\mathrm{R}$ & 50.0 \\
\hline PI 626580 & Yazd, Iran & $\mathrm{R}, \mathrm{MR}$ & $\mathrm{R}$ & 55.6 \\
\hline PI 621011 & West Azerbaijan, Iran & $\mathrm{R}, \mathrm{MR}$ & $\mathrm{R}$ & 50.0 \\
\hline PI 624152 & Hamadan, Iran & $\mathrm{R}, \mathrm{MR}$ & $R$ & 70.6 \\
\hline PI 625147 & Markazi, Iran & $\mathrm{R}, \mathrm{MR}$ & $\mathrm{R}$ & 53.8 \\
\hline PI 626074 & Kerman, Iran & $\mathrm{R}, \mathrm{MR}$ & $\mathrm{R}$ & 52.4 \\
\hline PI 626116 & Kerman, Iran & $\mathrm{R}, \mathrm{MR}$ & $\mathrm{R}$ & 68.8 \\
\hline PI 626608 & Yazd, Iran & $\mathrm{R}, \mathrm{MR}$ & $\mathrm{R}$ & 63.2 \\
\hline PI 626578 & Yazd, Iran & $\mathrm{R}, \mathrm{MR}$ & $\mathrm{R}$ & 82.4 \\
\hline PI 626590 & Yazd, Iran & $\mathrm{R}, \mathrm{MR}, \mathrm{MS}$ & $\mathrm{R}$ & 50.0 \\
\hline PI 572652 & Kazakhstan & $\mathrm{R}, \mathrm{MR}, \mathrm{MS}$ & $\mathrm{R}$ & 52.4 \\
\hline PI 626081 & Kerman, Iran & $\mathrm{R}, \mathrm{MR}, \mathrm{MS}$ & $\mathrm{R}$ & 66.7 \\
\hline PI 626111 & Kerman, Iran & $\mathrm{R}, \mathrm{MR}, \mathrm{MS}$ & $\mathrm{R}$ & 75.0 \\
\hline PI 626417 & Esfahan, Iran & $\mathrm{R}, \mathrm{MR}, \mathrm{MS}$ & $\mathrm{R}$ & 63.2 \\
\hline PI 626538 & Esfahan, Iran & $\mathrm{R}, \mathrm{MR}, \mathrm{MS}$ & $\mathrm{R}$ & 80.0 \\
\hline PI 625140 & Markazi, Iran & $\mathrm{R}, \mathrm{MR}, \mathrm{MS}, \mathrm{HS}$ & $\mathrm{R}$ & 50.0 \\
\hline PI 626416 & Esfahan, Iran & $\mathrm{R}, \mathrm{MR}, \mathrm{MS}, \mathrm{S}$ & $\mathrm{R}$ & 66.7 \\
\hline PI 626066 & Kerman, Iran & $\mathrm{R}, \mathrm{MR}, \mathrm{S}$ & $\mathrm{R}$ & 84.2 \\
\hline PI 625297 & Mazandaran, Iran & $\mathrm{R}, \mathrm{MR}, \mathrm{MS}$ & $\mathrm{R}$ & 60.0 \\
\hline PI 626581 & Yazd, Iran & $\mathrm{R}, \mathrm{MR}, \mathrm{S}$ & $\mathrm{R}$ & 66.7 \\
\hline PI 135064 & Afghanistan & $\mathrm{R}, \mathrm{MS}$ & $\mathrm{R}$ & 50.0 \\
\hline PI 623611 & West Azerbaijan, Iran & $\mathrm{R}, \mathrm{MR}$ & $\mathrm{R}$ & 50.0 \\
\hline PI 625295 & Mazandaran, Iran & $\mathrm{R}, \mathrm{MR}$ & $\mathrm{R}$ & 50.0 \\
\hline PI 626641 & Yazd, Iran & $\mathrm{R}, \mathrm{MR}$ & $\mathrm{R}$ & 70.0 \\
\hline PI 627241 & Semnan, Iran & $\mathrm{R}, \mathrm{MR}$ & $\mathrm{R}$ & 66.7 \\
\hline PI 626929 & West Azerbaijan, Iran & $\mathrm{R}, \mathrm{MR}, \mathrm{MS}$ & $\mathrm{R}$ & 54.5 \\
\hline PI 626594 & Yazd, Iran & $\mathrm{R}, \mathrm{S}$ & $\mathrm{R}$ & 50.0 \\
\hline
\end{tabular}

${ }^{+} \mathrm{R}$, resistant; MR, moderately resistant; MS, moderately susceptible; S, susceptible; HS, highly susceptible.

resistance sources. Previously, one of the heterogeneous resistant accessions identified here, PI 626580, was purified and the resistance gene, designated as Dn626580, was mapped to the short arm of chromosome 7D (Valdez et al., 2012). Furthermore, we also noted MR plants in 223 landrace accessions, and the remaining 137 accessions did not contain any resistant plants. Thus, most of these landraces, which were mainly collected from Iran, have the potential to be used as RWA2 resistance sources. Iran is one of the countries where RWA is endemic, and three known RWA resistance genes, including Dn1, Dn6, and Dn626580, originated from Iranian landraces. Iranian landraces may also be valuable resistance sources for newly discovered RWA biotypes.

To confirm resistance sources identified in this study, 27 homogeneous $\mathrm{R}$ or MR accessions, and 28 heterogeneous accessions with $\mathrm{HR}$ plants were retested. In general, results were in agreement with those of preliminary screening with one exception of PI 625154. In PI 625154, in addition to the HR and MR plants identified in the preliminary assay, HS plants were also identified in the confirmation test, suggesting that caution must be taken when using unpurified resistance sources.

\section{Reselection of RWA2 Resistance from Iranian Landraces}

In the first assay, we identified 15 landraces collected from Iran and made reselections since 2008. After two to three cycles of selection, 220 lines were identified for further evaluation. In this study, we tested the 15 Iranian landraces and all reselected lines. The RWA assay results of landraces were consistent with those obtained in the first screening. Highly resistant plants were identified in PI 626759, PI 627410, and PI 627628 (Table 3), and R plants in 12 other landraces (not listed in Table 4 because $\mathrm{R}$ plants accounted for less than $50 \%$ of the total in each of these accessions). From the 220 reselections, we obtained homogeneous HR or $\mathrm{R}$ lines derived from seven landraces (Table 1). One of them, PI 626759-20-32, offered a high level of resistance. Given that PI 626759 is a landrace, the resistance gene in this reselection is unlikely the rye-derived $D n 7$ gene. Further characterization of this line may provide an ideal alternative to $D n 7$ for introgression of RWA resistance. PI 626759-20-32 and homogeneous R lines derived from six other landraces, including PI 627843, PI 626612, PI 626926, PI 627625, PI 627828, and PI 624151, can be used in wheat breeding to enhance RWA2 resistance.

Some reselections derived from PI 627410, PI 625893, and PI 627583 still produced heterogeneous reactions, suggesting that the genetic backgrounds of HR or R plants in these landraces may be complex, or among-plant variation may be highly sensitive to microenvironmental changes. Of the 30 reselected lines derived from PI 627410, we identified two lines for further selection including PI 62741015-5 and PI 627410-23-1. All plants of PI 627410-15-5 were rated as either HR or R. Interestingly, we found that most aphids moved from the HR plants to $\mathrm{R}$ plants about $10 \mathrm{~d}$ after infestation, suggesting that different mechanisms, antixenosis and antibiosis, might be involved in HR and R plants, respectively. In PI 627410-23-1, although the majority of plants were rated as $\mathrm{HR}$ or $\mathrm{R}$, a considerable number of plants were rated as HS. The RWA2 resistance of PI 627410 may be controlled by multiple genes

Similarly, two selected lines derived from PI 625893 and PI 627583 were also heterogeneous. We will continue selection to derive $\mathrm{R}$ lines from them. None of the 36 reselected lines derived from PI 628178, PI 627681, PI 627727, PI 627687, and PI 628178 were rated as R or HR. Most of these lines showed moderate resistance when heavily infested at an initial density of about 30 RWA per leaf, which may provide only limited protection. However, the combination 
of MR genes in these landraces with other R genes may enhance the RWA resistance and prolong the application of $\mathrm{R}$ genes in wheat breeding and wheat production.

\section{Use of Novel RWA2 Resistance Sources}

Wheat germplasm collected from regions where RWA is endemic provides fundamental materials for genetic improvement of RWA resistance to help ensure food security for the world's rapidly growing population (El Bouhssini et al., 2011). Advances in translational genomics have highlighted the need of homogeneous resistance sources for gene mapping, gene cloning, and molecular breeding. However, as shown in this study, most RWA-resistant germplasm produce heterogeneous reactions in industrystandard, controlled-environment assays. This may be attributed to the genetic nature of landraces, which might be collected as heterogeneous mixtures or heterozygous populations. The resistance heterogeneity may result in inconsistent results between different groups because the same germplasm may or may not contain the same genotype. Moreover, it may hinder the application of novel genomic technologies in wheat genetic improvement. For example, whole-genome resequencing is revolutionizing diversity studies, genome-wide association mapping, and biparental population mapping (Xu et al., 2013), and one of its prerequisites is homogeneity. Thus, it is imperative to purify resistance sources. In this study, we made reselections from 15 resistant germplasm. After 2 to $3 \mathrm{yr}$ of selection, we were able to arrive at homogeneous HR or $\mathrm{R}$ lines from seven of them, and MR lines from five of them. We do not know the exact reasons why some progenies of three other landraces produced heterogeneous reactions to RWA2 infestation, but we did observe that a small number of spikelets flowered with an open glume in one reselection. Further studies are necessary to understand their genetic and physiological bases and to obtain homogeneous HR or R lines.

Apart from PI 626580 and CItr 2401, the resistance genes present in most lines identified in this study have not been identified. Given that most of these lines originated from Iran and pedigree information was not available, characterization of these novel resistance sources is imperative for their efficient use in wheat breeding. First, it is necessary to characterize these resistance sources in term of antixenosis, antibiosis, and tolerance and to prioritize those meeting requirements of our breeding objectives. For example, antixenosis is considered an important component of resistance (Webster and Inayatullah, 1988). However, in modern agricultural practice where monoculture predominates, antixenosis may not be an ideal defense for wheat production because RWA deprived of their preferred host may eventually accept a less preferred one (Crespo-Herrera 2012). Second, genomic studies may provide vital information and tools for their application in wheat breeding. Diversity studies based on molecular markers help breeders to deploy these resistance sources, and molecular mapping locates resistance genes and provides markers for marker-assisted selection. Currently, a study aimed at selection of a core set of RWA resistant sources and characterization of resistances and the underlying genes is underway at the Wheat, Peanut, and Other Field Crop Research Unit of USDA-ARS.

\section{Acknowledgments}

We thank Dr. Harold Bockelman of USDA-ARS National Small Grain Collection for providing some of the germplasm used in this study and Todd Lenger for his excellent technical support. Mention of trade names or commercial products in this article is solely for the purpose of providing specific information and does not imply recommendation or endorsement by the USDA. The USDA is equal-opportunity provider and employer.

\section{References}

Berzonsky, W.A., H. Ding, S.D. Haley, M.O. Harris, R.J. Lamb, R.I.H. McKenzie, H.W. Ohm, F.L. Patterson, F.B. Peairs, D.R. Porter, R.H. Ratcliffe, and T.G. Shanower. 2003. Breeding wheat for resistance to insects. Plant Breed. Rev. 22:221-296.

Burd, J.D., D.R. Porter, G.J. Puterka, S.D. Haley, and F.B. Peairs. 2006. Biotypic variation among north American Russian wheat aphid (Homoptera: Aphididae) populations. J. Econ. Entomol. 99:1862-1866. doi:10.1603/0022-0493-99.5.1862

Collins, M.B., S.D. Haley, F.B. Peairs, and J.B. Rudolph. 2005. Biotype 2 Russian wheat aphid resistance among wheat germplasm accessions. Crop Sci. 45:1877-1880. doi:10.2135/cropsci2004.0730

Crespo-Herrara, L.A. 2012. Resistance to aphids in wheat: From a plant breeding perspective. ISSN 1654-3580. Swedish University of Agricultural Sciences, Alnarp.

Dhaliwal, A.S., and F.J. MacRitchie. 1990. Contributions of protein fractions to dough handling properties of wheat-rye translocation cultivars. J. Cereal Sci. 12:113-122. doi:10.1016/ S0733-5210(09)80093-3

Dong, H., J.S. Quick, and Y. Zhang. 1997. Inheritance and allelism of Russian wheat aphid resistance in several wheat lines. Plant Breed. 116:449-453. doi:10.1111/j.1439-0523.1997.tb01029.x

El Bouhssini, M., K. Street, A. Amri, M. Mackay, F.C. Ogbonnaya, A. Omran, O. Abdalla, M. Baum, A. Dabbous, and F. Rihawi. 2011. Sources of resistance in bread wheat to Russian wheat aphid (Diuraphis noxia) in Syria identified using the focused identification of germplasm strategy (FIGS). Plant Breed. 130:96-97. doi:10.1111/j.1439-0523.2010.01814.x

Graybosch, R.A., C.J. Peterson, L.E. Hansen, and P.J. Mattern. 1990. Relationships between protein solubility characteristics, 1BL/1RS, high molecular weight glutenin composition, and end-use quality in winter wheat germplasm. Cereal Chem. 67:342-349.

Graybosch, R.A., C.J. Peterson, L.E. Hansen, D. Worral, D.R. Shelton, and A.J. Lukaszewski. 1993. Comparative flour quality and protein characteristics of $1 \mathrm{BL} / 1 \mathrm{RS}$ and 1AL/1RS wheat-rye translocations. J. Cereal Sci. 17:95-106. doi:10.1006/jcrs.1993.1010 
Haley, S.D., F.B. Peairs, C.B. Walker, J.B. Rudolph, and T.L. Randolph. 2004a. Occurrence of a new Russian wheat aphid biotype in Colorado. Crop Sci. 44:1589-1592. doi:10.2135/ cropsci2004.1589

Haley, S.D., J.S. Quick, J.J. Johnson, F.B. Peairs, J.A. Stromberger, S.R. Clayshulte, B.L. Clifford, J.B. Rudolph, O.K. Chung, and B.W. Seabourn. 2004b. Registration of 'Ankor' wheat. Crop Sci. 44:1025-1026. doi:10.2135/cropsci2004.1025

He, Z.H., S. Rajaram, Z.Y. Xin, and G.Z. Huang, editors. 2001. A history of wheat breeding in China. CIMMYT, D.F., Mexico.

Lapitan, N.L.V., J. Peng, and V. Sharma. 2007. A high-density map and PCR markers for Russian wheat aphid resistance gene Dn7 on chromosome 1RS/1BL. Crop Sci. 47:811-820. doi:10.2135/cropsci2006.08.0529

Liu, X.M., C.M. Smith, B.S. Gill, and V. Tolmay. 2001. Microsatellite markers linked to six Russian wheat aphid resistance genes in wheat. Theor. Appl. Genet. 102:504-510. doi:10.1007/s001220051674

Ma, Z.Q., A. Saidi, J.S. Quick, and N.L.V. Lapitan. 1998. Genetic mapping of Russian wheat aphid resistance genes Dn2 and Dn4 in wheat. Genome 41:303-306. doi:10.1139/gen-41-2-303

Mago, R., W. Spielmeyer, G. Lawrence, E. Lagudah, J. Ellis, and A. Pryor. 2002. Identification and mapping of molecular markers linked to rust resistance genes located on chromosome 1RS of rye using wheat-rye translocation lines. Theor. Appl. Genet. 104:1317-1324. doi:10.1007/s00122-002-0879-3

Marais, G.F., M. Horn, and F. Dutoit. 1994. Intergeneric transfer (rye to wheat) of a gene(s) for Russian wheat aphid resistance. Plant Breed. 113:265-271. doi:10.1111/j.1439-0523.1994.tb00735.x

Martin, T.J., A. Fritz, and J.P. Shroyer. 2001. Stanton hard red winter wheat. Kansas State Univ. Agric. Exp. Stn. Coop. Ext. Serv. PubL-L 921. Kansas State Univ. Manhattan, KS.

Martin, D.J., and B.G. Stewart. 1990. Dough stickiness in ryederived wheat cultivars. Euphytica 51:77-86. doi:10.1007/ BF00022895

Navabi, Z., B. Shiran, and M.T. Assad. 2004. Microsatellite mapping of a Russian wheat aphid resistance gene on chromosome $7 \mathrm{~B}$ of an Iranian tetraploid wheat line: Preliminary results. Cereal Res. Commun. 32:451-457.

Nkongolo, K.K., J.S. Quick, A.E. Limin, and D.B. Fowler. 1991. Sources and inheritance of resistance to Russian wheat aphid in Triticum species amphiploids and Triticum tauschii. Can. J. Plant Sci. 71:703-708. doi:10.4141/cjps91-103

Peng, J., H. Wang, S.D. Haley, F.B. Peairs, and N.L. Lapitan. 2007. Molecular mapping of the Russian wheat aphid resistance gene in wheat. Crop Sci. 47:2418-2429. doi:10.2135/ cropsci2007.03.0137

Porter, D.R., C.A. Baker, B.F. Carver, and G.F. Marais. 2007. Registration of STARS 0601W wheat germplasm. J. Plant Reg. 1:170. doi:10.3198/jpr2006.11.0730crg

Porter, D.R., C.A. Baker, and J.A. Webster. 1998. Inheritance of Russian wheat aphid resistance in PI 140207 spring wheat. Plant Breed. 117:293-294. doi:10.1111/j.1439-0523.1998.tb01944.x

Quick, J.S., G.E. Ellis, R.M. Normann, J.A. Stromberger, J.F. Shanahan, F.B. Peairs, J.B. Rudolph, and K. Lorenz. 1996. Registration of 'Halt' wheat. Crop Sci. 36:210.

Quick, J.S., S.D. Haley, J.A. Stromberger, S. Clayshulte, B. Clifford, J.J. Johnson, F.B. Peairs, J.B. Rudolph, and K. Lorenz. 2001a. Registration of 'Prowers 99' wheat. Crop Sci. 41:929. doi:10.2135/cropsci2001.413929x
Quick, J.S., J.A. Stromberger, S. Clayshulte, B. Clifford, J.J. Johnson, F.B. Peairs, J.B. Rudolph, and K. Lorenz. 2001b. Registration of 'Prairie Red' wheat. Crop Sci. 41:1362-1363. doi:10.2135/cropsci2001.4141362x

Quick, J.S., J.A. Stromberger, S. Clayshulte, B. Clifford, J.J. Johnson, F.B. Peairs, J.B. Rudolph, and K. Lorenz. 2001c. Registration of 'Prowers' wheat. Crop Sci. 41:928-929. doi:10.2135/ cropsci2001.413928x

Quick, J.S., J.A. Stromberger, S. Clayshulte, B. Clifford, J.J. Johnson, F.B. Peairs, J.B. Rudolph, and K. Lorenz. 2001d. Registration of 'Yumar' wheat. Crop Sci. 41:1363-1364. doi:10.2135/cropsci2001.4141363x

Singh, N.K., and K.W. Shepherd. 1988. Linkage mapping of genes controlling endosperm storage proteins in wheat. Theor. Appl. Genet. 75:628-641. doi:10.1007/BF00289132

Smith, M.C., T. Belay, C. Stauffer, P. Stary, I. Kubeckova, and S. Starkey. 2004. Identification of Russian wheat aphid (Homoptera: Aphididae) populations virulent to the Dn4 resistance gene. J. Econ. Entomol. 97:1112-1117. doi:10.1603/00220493(2004)097[1112:IORWAH]2.0.CO;2

Smith, M.C., D.J. Schotzko, R.S. Zemetra, and E.J. Souza. 1992. Categories of resistance in plant introductions of wheat resistant to the Russian wheat aphid (Homoptera: Aphididae). J. Econ. Entomol. 85:1480-1484.

Valdez, V.A., P.F. Byrne, N.L. Lapitan, F.B. Peairs, A. Bernardo, G. Bai, and S.D. Haley. 2012. Inheritance and genetic mapping of Russian wheat aphid resistance in Iranian wheat landrace accession PI 626580. Crop Sci. 52:676-682. doi:10.2135/ cropsci2011.06.0331

Webster, J.A., and C. Inayatuliah. 1988. Assessment of experimental designs for green bug (Homoptera: Aphididae) antixenosis tests. J. Econ. Entomol. 81:1246-1250.

Weiland, A.A., F.B. Peairs, T.L. Ranpolph, J.B. Rudolph, S.D. Haley, and G.J. Puterka. 2008. Biotypic diversity in Colorado Russian wheat aphid (Hemiptera: Aphididae) populations. J. Econ. Entomol. 101:569-574. doi:10.1603/00220493(2008)101[569:BDICRW]2.0.CO;2

Xu, X., L. Zeng, Y. Tao, T. Vuong, J. Wan, R. Boerma, J. Noe, Z. Li, S. Finnerty, S.M. Pathan, J.G. Shannon, and H.T. Nguyen. 2013. Pinpointing genes underlying the quantitative trait loci for root-knot nematode resistance in palaeopolyploid soybean by whole genome resequencing. Proc. Natl. Acad. Sci. USA 110:13469-13474. doi:10.1073/pnas.1222368110

Zhang, B., Q.R. Edwards, L. Kang, and S.J. Fuller. 2012. Russian wheat aphids (Diuraphis noxia) in China: Native range expansion or recent introduction? Mol. Ecol. 21:2130-2144. doi:10.1111/j.1365-294X.2012.05517.x

Zhang, D., G. Bai, C. Zhu, J. Yu, and B.F. Carver. 2010. Genetic diversity, population structure, and linkage disequilibrium in U.S. Elite winter wheat. Plant Genome 3:117-127. doi:10.3835/plantgenome2010.03.0004

Zhang, R.Z., H.B. Liang, and G.X. Zhang. 1999a. Research on Russian wheat aphid, Diuraphis noxia Kurdjumov, in China (In Chinese, with English abstract). Acta Entomologica Sinica 42S:11-17.

Zhang, R.Z., H.B. Liang, and G.X. Zhang. 1999b. Russian wheat aphid, Diuraphis noxia, and its research progress worldwide (In Chinese, with English abstract). Acta Entomologica Sinica 42S:130-140. 